\title{
Akademik Kadrolar Açısından Norm Kadro Uygulamalarına Genel Bir Bakış
} (Araştırma Makalesi)

\author{
An Overview of Norm Staff Practices in Academic Staff \\ Doi: 10.29023/alanyaakademik.888879
}

\section{Hava TAHTALIOĞLU}

Dr. Öğr. Üyesi, Niğde Ömer Halisdemir Üniversitesi, İktisadi ve İdari Bilimler Fakültesi,

Kamu Yönetimi Bölümü

htahtalioglu@gmail.com

Orcid No: 0000-0003-4698-4650

Bu makaleye atıfta bulunmak için: Tahtalıŏ̆lu, H. (2021). "Akademik Kadrolar Açısından Norm Kadro Uygulamalarına Genel Bir Bakış. Alanya Akademik Bakış”, 5(2), Sayfa No.1107-1124.

\section{Anahtar kelimeler: \\ Norm Kadro, Akademik Personel, Akademide Norm Kadro}

Makale Geliş Tarihi: 01.03.2021

Kabul Tarihi:

24.05.2021

\section{ÖZET}

Kamu personel sistemlerinde nicel ve nitel yeterliliğe sahip personelin istihdamını sağlamak adına norm kadro uygulamaları dikkat çekmektedir. Ayrıca kamusal hizmetlerin etkin ve verimli sunulmasi, kamusal kaynakların yerinde kullanımı açısından özellikle personel istihdamında norm kadro uygulamalarının gerekliliği yadsınamaz. Ancak Türkiye'de kamusal alanlarda norm kadro uygulamaları personel çeşitliliğinden dolayı hem istihdam boyutunda hem de terfi standartlarında çeşitli sorunlar beraberinde getirmektedir.

Çalışmanın amacı, kamu personel sisteminde özel kanun hükümlerine tabi olan akademik personelin istihdam ve terfileri açısından norm kadro uygulamalarının ortaya çıkardığı/çıkarabileceği çeşitli sorunlara dikkat çekmektir. Bu kapsamda öncelikle Türkiye'deki kamusal istihdam türü içinde akademik personelin yeri tespit edilmektedir. Akabinde norm kadro uygulamalarının gelişimi ve akademik alanda 2018 yılında yayımlanan "Devlet Yüksekögretim Kurumlarında Öğretim Elemanı Norm Kadrolarının Belirlenmesine ve Kullanılmasına İlişkin Yönetmelik” irdelenmiştir. Ek olarak literatüre yansiyan eserlerde norm kadro sistemine yönelik gözlemlenen sonuçlar dile getirilmiştir. Sonuç olarak akademik personel açısından norm kadro uygulamalarının istihdam ve özellikle terfide ciddi sorunlara neden olacă̆ı çıkarımında bulunulmuştur.

\section{ABSTRACT}

Keywords:

Norm staff practices draw attention in public personnel systems in order to ensure the employment of personnel with qualitative and quantitative qualifications. In addition, the necessity of norm staff practices in personnel employment is undeniable in order to provide public services effectively and efficiently and to use public resources appropriately. However, there are staff diversity in the public sector in Turkey. Therefore, norm staff practices create problems in both employment and promotion.

The study aims to draw attention to problems that may arise with the norm staff that employment and promotion of the academic staff subject to the 
provisions of special laws in Turkey. Firstly, place of academic staff in public employment species in Turkey is determined. Then, the development of norm staff in the public sector and the state university academicians norm staff regulation published in 2018 were examined. In addition, other studies in the literature dealing with the norm staff system in universities are discussed. As a result, it has been determined that various problems will arise in employment and especially promotion with the practice of norm staff brought to academics.

\section{GİRIŞ}

Fransızca kökenli olan norm sözcüğünün anlamı; "yargılama ve değerlendirmenin kendisine göre yapıldığı ölçüt, uyulması gereken kural, düzgü” ile “önceden belirlenmiş kalıp, düzgü” şeklindedir (https://sozluk.gov.tr/). Kadro, sözcügü ise Latince'de; kare, çerçeve, iskelet, çekirdek (Bozkurt, Ergun ve Sezen, 1998: 125), İtalyanca'da; “bir kamu kuruluşunun, bir işletmenin, denetim veya yönlendirme işlerini gerçekleştirenler ve bunların taşıdığı ödev, yetki ve sorumlulukların hepsi" (https://sozluk.gov.tr/) ya da "hizmetin örgütlenmesi" (Ayman-Güler, 2013: 78) anlamlarına gelmektedir. Başka bir tanımda ise "memurun çalıştığ1 belirli bir görev yeri ve/veya yapacağı iş, onun kadrosu ile ilişkili" bir kavram olarak ifade edilmektedir (Şaylan, 2000: 35).

Norm kadro; "bir işletme, kuruluş ya da birimin belirlenen amacına ulaşabilmesi için, kullandığı teknoloji de göz önünde tutularak amacı doğrultusunda yapması gereken işlerin iş yüküne göre orada istihdam edilmesi gerekli personel sayısının nitelikleri itibariyle saptanmasıdır" (Timur, 2004: 203). Kuruluşlarda personel istihdamının sayısal ve niteliksel olarak belirlenmesi ve standart bir ölçüye bağlanması, iş analizleri ve iş/görev tanımları yapılarak değerlendirilen norm kadro standartlarıyla sağlanmaktadır (Bilgin ve Aytürk, 2003: 159; Eren, 2006: 132). Başka bir tanımda ise norm kadro, kuruluş ya da işletmede önceden belirlenen amaca ulaşılabilmesi için ihtiyaç duyulan personel sayısının nitelikleri itibariyle belirlenmesi yanında personelin temin edilmesini (Demirkan, 2003: 15), muhafazasını ve geliştirilmesini içeren bir süreç olarak görülmektedir. Örgütsel yapılar içinde insan kaynağının planlanması, teknik ve sayısal boyutların yanı sıra davranışsal, psikolojik ve sosyal boyutları içine alan bir dizi olguyu içermektedir. Dolayısıyla insan kaynağı planlamasında diğer örgütsel unsurlardan oldukça zor bir süreç yürütülmektedir (Özer vd. 2019: 429-431). Bu süreç örgütlerde stratejik planlama sürecinin gelişimi ile örgütün başarısı açısından büyük önem taşıyan insan kaynağının stratejik planını gündeme getirmiştir (Aykaç, 1999: 119-120).

Norm kadroların saptanmasında iki temel yöntemden bahseden Timur (2004: 204), bunları iş ölçümü (zaman etüdü) ve iş örneklemesi olarak ifade etmektedir. Norm kadronun saptanmasında kullanılan ikinci temel yöntem olan iş örneklemesi yönteminin aksine iş ölçüm yöntemi bir dizi süreçten oluşmaktadır. Bunlar; "iş analizlerinin yapılması, işin öğelere ayrılması ve zamanlaması, çalışma hızının derecelendirilmesi ve normal zamanın saptanması, eklenecek payların belirlenmesi, normal zamana payların eklenmesi suretiyle standart zamanın saptanması ve nihayet norm kadronun belirlenmesi” şeklinde sıralanır (Timur, 2004: 204-211).

Tanımı yapılmış, standartları ve nitelikleri belirlenmiş, iş ve pozisyonlara uygun kişilerin seçilmesinin sağlandığı norm kadro düzenlemeleri, personel sistemine ilişkin birçok sorunu 
ve siyasal kayırmaları engelleyecektir (Tortop vd. 2013: 499). Norm kadronun uygulanmasındaki amaç işletme, kurum ya da birimlerde gereksiz istihdamın önüne geçilerek iş gücü verimliliğinin artırılmasıdır (Timur, 2004: 203). Kamu personel sisteminde performans değerlendirmesinin sağlıklı ve gerçekçi olabilmesinin yolu da norm kadro standartlarının belirlenmesinden geçmektedir (Kestane, 2003: 139). Dolayısıyla norm kadro, kadroların standardizasyonlarıyla birlikte işe uygun çalışan istihdamını sağlayan bir uygulamadir.

Norm kadro uygulamalarının kamu sektörü ve çalışanı açısından sunmuş olduğu yararlar;

- Belirlenen norm kadro, personelin seçimi ve terfisinde işin gereklerine uygun nitelikte ve sayıda istihdamı sağlarken yönetime olan güveni de pekiştirmektedir.

- Mevcut durumda istihdam edilen personelin bilgi ve becerisini işe uygun olarak kullanmasını sağlayacak eğitim ihtiyaçları da analiz edilir.

- Kadro unvanlarının belirginleşmesine ve standart hale gelmesine olanak tanıyarak personel yönetiminde tarafsızlığı ve objektifliği sağlamakta, liyakate uygun terfilerin yolunu açmaktadır.

- Personel giderleri ve bütçe arasında denge sağlamaktadır.

- Kurumlar arası kadro, meslek tanımları ve ücret standardizasyonu sağlamaktadır.

- İşe ve personele ilişkin istatistiki verilerin düzenli tutulması sağlanırken yöneticilerin bu verilerden etkin bir şekilde yararlanmasına imkân vermektedir.

- Kurum ya da birimlerde gereksiz istihdamın önüne geçilerek iş gücü verimliliğinin artırılmasına katkıda bulunmaktadır (Bilgin ve Aytürk, 2003: 159-160; Demirkan, 2003: 16; Timur, 2004: 203).

Norm kadro çalışmalarında ve uygulamalarında karşılaşılan ya da karşılaşılması muhtemel görülen çeşitli sorunlar vardır. Bu sorunların ilki, tepe yöneticilerin norm kadro çalışmalarına ve uygulamalarına ilişkin artıları görmeden sadece mevzuat gerekliliği olarak kabullenmesidir. İkincisi, iş görenlere uygulama hakkında yeterince bilgilendirme yapılmamasından dolayı norm kadro belirleme çalışmalarındaki iş analizi sürecinde yapılan anketlerde çalışanların eksik bilgiler verebilmeleridir. Üçüncü sorun ise, norm kadro uygulamalarına ilişkin açıklamaların yetersizliği veya belirsizliği iş görenlerin tepkisine yol açabilir. Norm kadroyla getirilen değişime dirençte dördüncü sorun, statü ve gelir kaybı korkusuyken; beşinci sorun, kültürel ve toplumsal alışkanlıklardan vazgeçememe olarak sıralanabilir (Demirkan, 2003: 17). Ayrıca norm kadro saptama yöntemleri açısından kamu sektöründe geleneksel iş etüdü yöntemlerinin uygulanması, personel beyanındaki gerçek dışı sürelerden dolayı, sakınca doğurabilmektedir (Sümer ve Erol, 2003: 111). Bunlara ek olarak; Türk kamu personelinin istihdamında ve terfisinde liyakat uygulamalarının yeterince belirleyici olmaması, terfilerde kişisel girişimlerin eksikliği, planlama alışkanlığının içselleştirilmemesi ve vizyoner bakış açılarının geliştirilmemesi norm kadro uygulamalarına karşı tepkilere neden olarak personel sisteminde zaten var olan sorunları daha da derinleştirecektir (Demir ve Demir, 2019: 2495). Aslında Taylorist felsefenin yeniden yorumlanması olarak kabul edilen norm kadro uygulamaları kamu personel sistemini derinden etkilemektedir (Yüceyılmaz ve Özgür, 2019: 82).

$\mathrm{Bu}$ çalışmada üniversitelerde istihdam ve terfi açısından norm kadro düzenlemesinin yerindeliği ve uygulamada karşılaşılan/karşılaşılacak sıkıntılar irdelenmektedir. Araştırma kapsamında akademik personelin kamu personel sistemi içindeki yerine dikkat çekilmiştir. 
Akabinde Türkiye'de kamu personel sisteminde norm kadro düzenlemesinin gelişim seyri incelenmiştir. Son olarak akademik personel için getirilen/geliştirilen norm kadro düzenlemeleri ele alınmış ve literatürde yayımlanan eserler kaynak gösterilerek karşılaşılan sorunlar ifade edilmiştir. Sonuçta norm kadro düzenlemeleriyle üniversitelerde istihdam ve terfide yaşanan/yaşanabilecek sorunlara dikkat çekilmiştir.

\section{AKADEMIK PERSONELiN TÜRKIYE'DEKi KAMU PERSONEL ÇEŞiTLiLiĞi İÇiNDEKi YERi ve KONUMU}

Türkiye'de kamu personeli hukuksal olarak memur ve diğer kamu görevlileri şeklinde adlandırılır. Diğer kamu görevlileri askeri, adli, akademik mesleklerden oluşmaktadır (Ayman-Güler, 2013: 78). Özkal-Sayan (2009) benzer şekilde Türkiye'deki kamu personel sisteminin idari, akademik, askeri ve adli alanlarda ayrı mevzuatlarla düzenlendiğine işaret etmektedir. Mevzuattaki bu farklılık düşünsel, tarihsel ve siyasal nedenlere bağlanmaktadır. Aslan (2012: 478) Türkiye'de kamu personel sistemi içindeki bu gruplandırmayı “1980 sonrası ortaya çıkan esnek kamu personel rejimi ...... Post-Fordist yönde ortaya çıkan saçaklanma" olarak ifade etmektedir. Kalkandelen (1972: 129-130) personel sistemi açısından yasal mevzuattaki çeşitliğin farklı ücret, dengesiz haklar ve çıkarlar elde etme gibi çeşitli ayrıcalıklar oluşturacağına dikkat çekmiştir. Bu grupların aynı yasal düzenlemeler çerçevesinde istihdamlarının bu ayrıcalıkları gidereceğini savunmaktadır. 2001 bunalımı sonrası kamu personel sistemindeki esnek yapının bütünsel olarak düzenlenmesi yönünde yapılan çalışmalar norm kadro düzenlemeleri özelinde gerçekleştirilmek istenmiştir (Aslan, 2012: 605). 2005 yılında hazırlanan Kamu Personel Yasa Tasarısı Taslağı da kamu personel sistemindeki bu ayrımı kısmen ortadan kaldırmayı hedeflemiştir (Ayman-Güler, 2013: 92). Özkal-Sayan (2009) ise kamu personel sistemi adına bütünleştirmeyi hedefleyen düzenlemelerin karmaşık yasal bir zemin oluşturacağını ifade etmektedir.

Günümüz Türkiye'sinde kamu personel istihdamını bütüncül olarak ele alan tek bir yasal düzenleme bulunmamaktadır. Öğretim üye ve yardımcıları, kamu personel sisteminde genel kanun niteliği taşıyan ve idari personeli düzenleyen 657 sayılı Devlet Memurları Kanunu' 'nu 1. maddesi son fikrasında sıralanan gruplar arasında yer almakta ve bunlara özel kanun hükümleri uygulanmaktadır. $\mathrm{Bu}$ çerçevede akademik personelle ilgili iki özel kanun karşımıza çıkmaktadır. Bunlar; 4 Kasım 1981 tarih ve 2547 sayılı Yükseköğretim Kanunu² ile 11 Ekim 1983 tarih ve 2914 sayılı Yükseköğretim Personel Kanun³'dur. 2914 sayılı Kanun'la öğretim üyeleri (profesör, doçent ve doktor öğretim üyesi), öğretim görevlileri ve araştırma görevlileri sınıfına ayrılan akademik personelin aylık, ödenek, derece ve kademe ilerlemesi gibi diğer özlük hakları; 2547 sayılı Kanun'unun hükümleriyle de görevleri ve atanmaları, çalışma ve denetim esasları düzenlenmiştir. Sosyal hakları yönünden ise 657 sayılı Kanun ile 2914 sayılı Kanun hükümlerine bakılması gerekmektedir (Kayar, 2020: 72). Aslında akademik personel memurun tabi olduğu hiyerarşiye tabi tutulamayacağından dolayı (Onar, 1952: 801) 1980'li yıllarda kendine özgü bir statüye kavuşturulmuştur. Akademik personelin genel memurluk statüsünden ayrılması üniversitelere Anayasal olarak özerklik tanınmasından da kaynaklıdır (Aslan, 2006: 351).

\footnotetext{
${ }^{1} 657$ sayılı Devlet Memurları Kanunu, RG: 13.07.1965, 12056.

22547 sayılı Yükseköğretim Kanunu, RG. 6.11.1981, 17506.

${ }^{3} 2914$ sayılı Yükseköğretim Personel Kanun, RG. 13.10.1983, 18190.

1110
} 
Çoklu yasal düzenleme kapsamında hakları, yükümlülükleri ve sorumlulukları belirlenen akademisyenlerin kamu personel sistemleri açısından kariyer (rütbe) sistemine mi, yoksa kadro (iş sınıflandırması) sistemine mi tabi oldukları irdelenmesi gereken bir diğer durumdur. Türkiye'deki kamu personel istihdam türleri personel sistemleri içinde değerlendirildiğinde Ayman-Güler (2013: 225) memur ve diğer kamu görevlilerinin kariyer sınıflandırılmasına tabi oldukları, sözleşmeli personel ile işçilerin iş sınıflandırmasına tabi olduklarını belirtmiştir. Bu kapsamda özel kanun hükümleriyle istihdam edilseler de diğer kamu görevlileri grubunda yer alan akademik personelin kariyer sınıflandırmasına tabi olduğu sonucu çıkmaktadır. Ancak akademisyenlik mesleğindeki doktor öğretim üyeliğii, araştırma görevliliği gibi bazı kadrolar için öngörülen idari hizmet sözleşmesiyle istihdam edilme unsuru akademide kadro sınıflandırılmasının da var olduğunu göstermektedir. Dolayısıyla akademik personel için 2547 ve 2914 sayılı Kanun'larda hem rütbe hem de kadro (iş) sinıflandırma sistemi kullanılmaktadır.

Anayasa Mahkemesi 2019 yılında vermiş olduğu bir kararda akademik personeli; 1982 Anayasası'nın 128. maddesinde "Devletin, kamu iktisadi teşebbüsleri ve diğer kamu tüzelkişilerinin genel idare esaslarına göre yürütmekle yükümlü oldukları kamu hizmetlerinin gerektirdiği asli ve sürekli görevler, memurlar ve diğer kamu görevlileri eliyle görülür" ifadesindeki diğer kamu görevlileri kategorisinde değerlendirmektedir. Kayar (2020: 29) da Türkiye'deki akademisyenleri diğer kamu görevlileri kategorisinde yer verdiği özel statülü diğer kamu görevlileri başlığında ele almış ve akademisyenlerin Anayasa'da belirtilen bu özellikleri yanı sıra atamayla kamu hizmetlerine katıldıkları ancak mesleki faaliyet alanlarındaki özgünlük nedeniyle kendi özel personel kanunlarının var olduğuna dikkat çekmiştir. $\mathrm{Bu}$ özgünlük öğretim üyeleri kadrolarına atama şekillerinde kendini göstermektedir. 2547 sayılı Kanun'un 23. maddesinde “doktor öğretim üyesi kadrosuna atama için öncelikle doktora ile tıpta, diş hekimliğinde, eczacılıkta ve veteriner hekimlikte uzmanlık unvanını veya Üniversitelerarası Kurulun önerisi üzerine Yükseköğretim Kurulu'nca (YÖK) tespit edilen belli sanat dallarının birinde yeterlik kazanmış" olma şartı bulunmaktadır. Bunlara ek olarak yükseköğretim kurumu, bilimsel kaliteyi artırmak amacıyla YÖK'ün onayını alarak, disiplinler arası farklılıkları gözeterek, objektif ve denetlenebilir nitelikte koşullar belirleyebilirler. Doktor öğretim üyeliği kadrosu idari hizmet sözleşmesinin var olduğu bir kadrodur. 23. maddenin a fikrasında atama işleminin rektör tarafından en çok dört yıl süre ile yapıldığına değinilmiş ve her atama süresi sonunda görevin sona ereceği açıkça dile getirilmiştir. İlgili kişi üniversitenin yeniden atanma kriterlerini karşılarsa ve başvurusu üzerine uygun görülürse yeniden atanabilmektedir.

2547 sayılı Kanun'un 24. maddesi hükümlerine göre Doçentlik, gerekli koşulları sağlayan (madde 24/a-1-2-3) adayların başvurusu üzerine Üniversitelerarası Kurul tarafından belirlenen jürilerin değerlendirmesi sonucunda hak edilen akademik bir kadrodur. Doçentliğe atanma kriterleri arasında bilimsel kaliteyi artırmak amacıyla yükseköğretim kurumları YÖK'ün onayını alarak objektif ve denetlenebilir nitelikte ek koşullar belirleyebilirler. Bu koşullar belirlenirken bilim/sanat dalları arasındaki farklılıkları göz önünde bulundurmalıdır. Belirlediği koşullar arasında sözlü sınav var ise bu sınav Üniversitelerarası Kurul tarafindan oluşturulacak jürilerce yapılır.

2547 sayılı Kanun'un 26. maddesine göre Profesörlüğe yükseltilerek atama kriterleri, akademisyenin doçentlik unvanını aldıktan sonra en az beş yıl süre içinde bilim alanında özgün yayın veya çalışmalar yapmasıyla gerçekleştirilir. Bunlara ek olarak üniversiteler 
YÖK'ün onayını almak suretiyle, yine bilimsel kaliteyi artırmak amaciyla, disiplinler arasındaki farklılıkları da gözeterek, objektif ve denetlenebilir kriterler belirleyebilir. Profesörlük kadrosuna başvuran adayların dosyaları ise en az üçü dışarıdan olmak kaydıyla beş profesöre değerlendirilmesi için gönderilmektedir. Gelen olumlu yanıtlar doğrultusunda atama işlemi yapılmaktadır.

Akademisyeni diğer kamu çalışanlarından ayıran bir diğer özellik ise görevlerinin kapsamıdır. Yükseköğretim kurumlarında istihdam edilen öğretim üyelerinin, önlisans, lisans ve lisansüstü düzeylerde eğitim-öğretim ve uygulamalı çalışmalar yapmak ve yaptırmak, proje hazırlıklarını ve seminerleri yönetmek, bilimsel araştırmalar ve yayımlar yapmak, belirli günlerde öğrencileri kabul ederek, onlara gerekli konularda yardım etmek, 2547 sayılı Kanun'daki amaç ve ana ilkeler doğrultusunda yol göstermek ve rehberlik etmek, yetkili organlarca verilecek diğer görevleri yerine getirmek gibi (2547 sayılı Kanun madde 22/a-b-cd-e) geniş kapsamlı birçok görevi bulunmaktadır.

\section{NORM KADRO DÜZENLEMELERININ GELIŞIMM SEYRİ}

1980'li yıllarda yönetim sistemlerinde yaşanan değişim talepleri kamu personel sisteminde de gündeme gelmiştir. Özellikle sıralanan birçok sorunla birlikte kamu çalışanlarının nitelik ve verimlilik sorununa odaklanarak değişimin gerekliliği vurgulanmıştır (Şaylan, 2000: 22-23). $\mathrm{Bu}$ değişim sürecine yön veren anlayış, proaktif yönetim kültürünü benimseyen, çağdaş performans değerlendirme tekniklerini kullanan örgütte insanın özne olduğu, ödül ve külfet dengesinin kurulduğu insan kaynakları yönetimi olmuştur (Aykaç, 1999: 31-32; Tortop vd. 2013: 498). İnsan kaynakları yönetimi çerçevesinde sağlanacak insan gücü planlaması; "moral, motivasyon, hakkaniyet duygusu ile kuruluşun yapısı, çalışma düzeni ve performansı arasında varsayılan verimlilik ilişkisine paralel olarak, bireyin beklentileri ile nitelik ve yeteneklerinin geliştirilmesi ve kullanılmasını bağdaştırmak anlamında verimliliği geliştirmektedir" (Öktem, 1990: 14-15). Kamu yönetiminde insan kaynakları planlaması aracı olarak norm kadro uygulamaları benimsenmiştir (İyem, vd., 2016: 184).

Türkiye özelinde yönetsel yapılardaki planlama sürecinin gündeme gelmesi 1960’lı yıllarla başlamıştır. Ancak personele ilişkin reformların yapılması daha sonraki dönemlere bırakılmıştır. Altıncı Beş Yıllık Kalkınma Planı’na (1990-1994) bakıldığında ilk kez insan gücü planlamasından bahsedildiği görülür. Bu planda mahalli idarelerin merkezi yönetimlerle birlikte insan gücü planlaması yaparak norm kadrolarını belirlemeleri gerektiği ifade edilir (DPT, 1989). Yedinci Beş Yıllık Kalkınma Planı'nın (1996-2000) Kamu Hizmetlerinde Etkinliğin Artırılması Projesi ve Kamu Kesiminde Ücret Adaletinin Sağlanması başlığında "kamu kesiminin yeniden yapılanması sürecinde istihdamın sayı, nitelik, verimlilik ve ücret düzeyi bakımından sağlıklı bir yapıya kavuşturulması için kamu kesimindeki istihdam gözden geçirilecek, kamu yönetiminin yeterli sayı ve nitelikte personelle donatılmasını ve personel kaynaklarının verimli ve yerinde istihdamını sağlamak üzere insan gücü planlaması yapılacak ve etkinliğin artırılması amacıyla iş analizlerine dayalı norm kadrolar hazırlanacak ve mevcut durumun olması gereken açısından değerlendirilebilmesi için kamu insan gücü envanteri çıkarılacak" şeklindeki ifadesiyle tüm kamu kurumlarını kapsayan norm kadro düzenlemesinden bahsedilmektedir (DPT, 1995). Sekizinci Beş Yıllık Kalkınma Planı (2001 2005) kapsamında önceki dönemde gerçekleştirilen kurumsal norm kadro düzenlemeleriyle önemli gelişmeler sağlandığına işaret edilerek tüm kamu kurumlarına yayılması gerektiği vurgulanmıştır (DPT, 2000). Dokuzuncu Kalkınma Planı (2007-2013) kamu kurum ve kuruluşlarında personel dağılımı dengesizliği ve yetersizliği norm kadro uygulamalarının 
yeterince yapılmamasına bağlamaktadır. Bu kapsamda norm kadro uygulamalarının yapılması gerektiğine işaret etmektedir (DPT, 2006). T.C. Kalkınma Bakanlığı (2013) tarafindan hazırlanan Onuncu Kalkınma Planı'yla (2014-2018); T.C. Cumhurbaşkanlığı Strateji ve Bütçe Başkanlığı (2018) tarafından hazırlanan On Birinci Kalkınma Planı'nda (2019-2023) norm kadro kavramına değinilmemiştir. Ancak her iki planda da nitelikli işgücüne dikkat çekilmiş ve bu iş gücünü sağlayacak nitelikte eğitimin oluşturulmasıyla birlikte ilgili eğitime erişimi kolaylaştırmanın önemi üzerinde durulmuştur. Özellikle Onuncu Kalkınma Planı'nda kariyer mesleklerde nitelikli insan gücü istihdamının teşvik edilmesi gerektiği düşünülürken düşük gelirli bölgelerde çalışmayı özendirerek nitelikli personel istihdamının sağlanması merkez-taşra, kurum ve kuruluşlar ile bölgeler arasındaki dengesizlikleri ortadan kaldıracağı düşünülmektedir.

1990’l1 yıllarda Türk kamu personel sisteminde gündeme getirilen norm kadro düzenlemeleri, kadro (iş sınıflandırması) sistemine geçiş olarak değerlendirilmiştir (Ayman-Güler, 2013: 268; Güneşer-Demirci, 2010: 164-165). Bu yüzden norm kadro düzenlemelerinin kamu personel sistemine adapte edilmesinde sorunlar yaşanmıştır. Şaylan (2000: 131) Türk kamu personel sistemindeki temel sorunlardan biri olan istihdamdaki fazlalığın-oransal farklılığın ana nedenini "norm kadro düzenlemelerinin yapılmamasina-sisteme adapte edilmemesine" bağlamaktadır.

Kamu personel sisteminde kadroların ihdası, iptali ve kullanılmasına dair esaslar 1983 yılında çıkarılan 190 sayılı Genel Kadro ve Usulü Hakkında KHK ${ }^{4}$ ile gerçekleştirilmekteydi (Şaylan, 2000: 35). Bu kapsamda 1999 yılında Sosyal Sigortalar Kurumu Başkanlığı merkez ve taşra teşkilatında istihdam edilecek personele ilişkin norm kadro sayılarının belirlenmesine olanak tanıyan Yönetmelik ${ }^{5}$ çıkarılmıştır. Ülkemizde kamu kesiminde norm kadro uygulamalarının ilk örneklerine Kamu İktisadi Teşebbüsleri'nde rastlanmaktadır. Kamu personel sistemi içinde 2000 yılı 1658 sayılı Kamu Kurum ve Kuruluşlarınca Yapılacak Norm Kadro Çalışmalarında Uyulacak Usul ve Esaslar'ın düzenlendiği Bakanlar Kurulu Kararı'yla ${ }^{6}$ yaygın şekilde gündeme gelmiştir. Akabinde Kamu Kurum ve Kuruluşlarınca Yürütülmekte Olan "Norm Kadro" Çalışmaları ile ilgili 2001/39 sayılı Başbakanlık Genelgesi' yle ${ }^{7}$ bakanlıklar, bağlı ve ilgili kuruluşlar, üniversiteler ve mahalli idareler 2001 2003 yılları arasında belirlenen takvime göre norm kadro çalışmalarını tamamlaması gerektiği vurgulanmıştır. Bu kapsamda kurum ve kuruluşlarının, Türkiye ve Orta Doğu Amme İdaresi Enstitüsü $^{8}$ (TODAİE), Milli Prodüktivite Merkezi $^{9}$ (MPM) ve üniversitelerden hizmet alarak norm kadro düzenlemelerini yapmaları önerilmiştir. Bu karara göre norm kadro çalışmalarına, kamu kurum ve kuruluşlarının amaçlarına en etkin ve verimli ulaşmasını sağlayacak şekilde mevcut durumlarını ele alan teşkilat (örgüt) analizi yapılmak suretiyle başlanmalıdır. Akabinde teşkilattaki her bir birim için iş analizi ve iş ölçümleri yapılarak gerekli

\footnotetext{
${ }^{4}$ 02.07.2018 tarih ve 703 sayılı Kanun Hükmünde Kararname'nin Geçici Madde 9'da belirtilen hüküm doğrultusunda yürürlükten kaldırılmıştır. Bkz. 703 sayılı Anayasada Yapılan Değişikliklere Uyum Sağlanması Amacıyla Bazı Kanun ve Kanun Hükmünde Kararnamelerde Değişiklik Yapılması Hakkında Kanun Hükmünde Kararname, RG. 09.07.2018, 30473.

${ }^{5}$ Sosyal Sigortalar Kurumu Başkanlığı Merkez ve Taşra Teşkilatının Norm Kadrolarına İlişkin Yönetmelik, RG. 17.12.1999, 23909

${ }^{6}$ Bakanlar Kurulu Kararı 2000/1658, RG. 20.12.2000, 24266.

7 2001/39 Sayılı Başbakanlık Genelgesi, RG. 11.07.2001, 24459

${ }^{8}$ 09.07. 2018 tarihli 703 sayılı KHK ile kapatılmış ve teşkilatı ve bütçesi YÖK'e devredilmiştir.

${ }^{9} 17$ Ağustos 2011 tarihinde Resmi Gazetede yayımlanan KHK'yle kapatılmış, T.C. (Bilim) Sanayi ve Teknoloji Bakanlığı ile birleştirilmiştir.
} 
kadrolar/pozisyonlar, her bir kadro/pozisyonun görev tanımları ve bu kadro/pozisyonlarda çalıştırılacaklarda aranacak nitelikler (iş gerekleri) belirlenmelidir. Bu doğrultuda birimler için gerekli kadro/pozisyon sayısı yani "Norm Kadro"ları oluşturulmalıdır (Bilgin ve Aytürk, 2003: 157-158; Timur, 2004: 202; Tortop vd. 2013: 499-500). 2001/39 say1lı Genelge ile kamu kurum ve kuruluşlarının özellikle istihdam politikalarında norm kadro düzenlemesine bir an önce başlamaları gerektiği vurgulanmış (Bilgin ve Aytürk, 2003: 157), buna ek olarak daha etkin bir yapılanmanın sağlanacağı üzerinde durulmuştur (Sümer ve Erol, 2003: 98).

2001 yılında kamu kurum ve kuruluşlarında norm kadro çalışmaları büyük bir ümitle başlanmış 2002 yılında yönetime gelen hükümet tarafından da benimsenmiştir. Ancak Kasım 2002'deki hükümetin kamu yönetimi reformu nedeniyle norm kadro uygulamaları Devlet Personel Başkanlığ ${ }^{10}$ (DPB) tarafından beklemeye alınmıştır. Diğer taraftan norm kadroyla ilişkili konuların ilgili kurumlar tarafından kapsamının çizilmemiş olması, kamu kurumlarındaki mali açıkların ve istihdam fazlasının belirlenmemiş olmasından dolayı hangi kurumlarda öncelikli uygulanacağına karar verilememesi, DPB tarafından geliştirilen "Norm Kadro El Kitabı"ndaki teknik eksiklikler, uygulamada kamu kurumlarıyla DPB ve Maliye Bakanlığı arasındaki koordinasyon eksikliği, kamu kurumlarında oluşturulan norm kadro ekiplerinin yapısal yetersizliği, kamusal hizmetler açısından gerekliliği görülen alanlardan ziyade özelleştirme politikaları çerçevesinde uygulanma eğilimleri gibi nedenlerden dolayı dönem itibariyle norm kadro düzenlemelerinden başarı beklentisi azalmış ve uygulanma olasılığ1 güçleşmiştir (Ömürgönülşen ve Öktem, 2004: 253-254).

Norm kadro çalışmaları; örgüt analizi yapılarak, görev tanımlarının belirlendiği ve norm kadro pozisyon kılavuzunun hazırlandığı süreçleri kapsamaktadır/kapsamalıdır (Tortop vd. 2013: 502). Örgütsel amaçlara ulaşmada önemli yeri olan insan kaynağı planlaması, özellikle eğitim sektöründe daha fazla önemli hale gelmektedir (Baki ve Acar, 2020: 142). Eğitim alanında 1990’lı yıllarda Milli Eğitim Bakanlığı bünyesinde karşımıza çıkan norm kadro uygulamaları 18 Haziran 2014 tarihli Millî Eğitim Bakanlığı'na Bağlı Eğitim Kurumları Yönetici ve Öğretmenlerinin Norm Kadrolarına İlişkin Yönetmelik'le ${ }^{11}$ günümüzdeki halini almiştır.

5393 sayılı Belediye Kanunu ile 5216 sayılı Büyükşehir Belediye Kanunu'na dayanılarak 2007 yılında yayımlanan yönetmelik ${ }^{12}$ çerçevesinde belediye ve bağlı birliklerinde norm kadro düzenlemeleri yapılmıştır. 5302 sayılı İl Özel İdaresi Kanunu'na dayanılarak 2007 yılında yayımlanan bir diğer yönetmelikle ${ }^{13}$, il özel idarelerinde norm kadro ilke ve standartları belirlenmiştir.

Türkiye'de 2018 yılında hükümet sisteminin değişimiyle birlikte çeşitli yasal ve düzenleyici işlemlerin yerini yenileri almıştır. Dolayısıyla yeni sistemde norm kadro düzenlemeleri adına 2 sayılı Genel Kadro ve Usulü Hakkında Cumhurbaşkanlığı Kararnamesi ${ }^{14}$ dikkat çekmektedir. Albayrak (2020) Cumhurbaşkanlığı sistemiyle gerçekleştirilen ve gerçekleştirilmesi ön görülen (kamu sektöründeki çalışanların yetenek ölçümü, tekrar

\footnotetext{
${ }^{10}$ 09.07.2018 tarihli 703 sayılı KHK ile 2019 yılı itibarıyla kapatılmış, tüm görevleri diğer kurumlara devredilmiştir.

${ }^{11}$ Millî Eğitim Bakanlığı'na Bağlı Eğitim Kurumları Yönetici ve Öğretmenlerinin Norm Kadrolarına İlişkin

Yönetmelik, RG. 18.06.2014, 29034.

${ }^{12}$ Belediye ve Bağlı Kuruluşları ile Mahalli İdare Birlikleri Norm Kadro İlke ve Standartlarına Dair Yönetmelik, RG. 22.02.2007, 26442.

${ }^{13}$ İl Özel İdareleri Norm Kadro İlke ve Standartlarına Dair Yönetmelik, RG. 10.06.2007, 26548.

${ }^{14} 2$ sayılı Genel Kadro ve Usulü Hakkında Cumhurbaşkanlığı Kararnamesi, RG. 10.07.2018, 30474.

1114
} 
yerleştirme ve norm kadro çalışmalarının yapılacağı) değişikliklerle Türkiye'nin kamu personel rejiminde esnekleşme hareketinin tekrar gündeme geldiğine işaret etmiştir.

\section{AKADEMIKK PERSONEL İÇIN NORM KADRO UYGULAMASI}

Akademik kadroların belirlenmesi, 703 sayılı Anayasada Yapılan Değişikliklere Uyum Sağlanması Amacıyla Bazı Kanun ve Kanun Hükmünde Kararnamelerde Değişiklik Yapılması Hakkında Kanun Hükmünde Kararname'nin geçici 10. maddesi gereği 78 sayılı Yükseköğretim Kurumları Öğretim Elemanlarının Kadroları Hakkında Kanun Hükmünde Kararname'nin kaldırılmasıyla şekil değiştirmiştir. Bu hüküm çerçevesinde akademik kadroların kullanımının, genel kadro ve usulüne ilişkin ilgili Cumhurbaşkanlığ 1 kararnamesinde belirleneceği ifade edilmiştir. 10 Temmuz 2018 tarih 2 sayılı CBK'nın 11. maddesi (13 Eylül 2018 tarihinde eklenen) 4. fikrasıyla "devlet yükseköğretim kurumları bünyesindeki birimler, önlisans, lisans ve lisansüstü programların sayısı, niteliği ve öğrenci sayıları ile yükseköğretim kurumunun eğitim-öğretim dışında yürüttüğü hizmetler dikkate alınarak Yükseköğretim Kurulunca çıkarılan norm kadro yönetmeliğine göre ilgili yükseköğretim kurumunca atama" yapılacağı belirtilmiştir. Kararnamedeki ilgili maddeye dayanılarak 2 Kasım 2018 tarihli Devlet Yükseköğretim Kurumlarında Öğretim Elemanı Norm Kadrolarının Belirlenmesine ve Kullanılmasına İlişkin Yönetmelik ${ }^{15}$ çıkarılmıştır. Bu yönetmelikle devlet üniversitelerindeki akademik kadrolarda norm kadro uygulamaları başlamıştır. Akademik açıdan norm kadro uygulamalarının gündeme gelişini Karataş ve Avcı (2019: 440) artan üniversite sayısına istinaden bu kurumların gelecekle ilgili belirsizliklerinin giderilmesi adına yapılmış yasal ve yönetsel düzenlemeler çerçevesinde değerlendirmektedir.

Yükseköğretim kurumlarında norm kadro standartlarını belirleyen yönetmelikte dikkat çeken ilk ifade asgari kadro sayısıdır (madde 3/a). Asgari kadro sayısı, "yükseköğretim kurumlarında bir programın eğitim öğretime başlamak ve devam edebilmek için gerekli asgari öğretim elemanı sayısının belirlenmesi” şeklinde tanımlanmıştır. Bu sayının belirlenmesinde YÖK etkin rol oynamaktadır. Fakülte veya bölüme öğrenci alan lisans programlarında toplam öğretim üyesi kadrosu asgari kadro sayısının altında olamayacağı belirtilmiştir (madde 4/1). Asgari kadroların kullanımı rektöre bırakılmışsa da öğrencisi bulunan birimlerin asgari kadrolarında boşalma olması halinde bu sayıya bir an önce ulaşılması için uygun kadroya ilk ilanda yer verilmesi gerektiği vurgulanmıştır (madde5/2).

Yönetmelikle dikkat çekilen bir diğer kavram norm kadrodur (madde 3/c). Yükseköğretim kurumlarındaki bir bölüm, analim/anasanat dalı veya programda eğitim, öğretim, araştırma ve diğer hizmetlerin sürdürülebilmesi için gerekli olan öğretim elemanı kadrosudur. Norm dişı kadro (madde 3/b) kavramı ise "ilgili yönetmelik çerçevesinde belirlenen norm kadro sayısı dışında kalan ancak ilgili yükseköğretim kurumunun ihtiyacı olduğunu gerekçeli olarak belirttiği öğretim elemanı” kadrosudur.

Üniversitedeki norm kadro dağılımı; ön lisans ve lisans düzeyinde öğrenci alan birimler ile bünyesinde lisans eğitimi olmasa da servis dersler veren birimler ve bünyesinde anabilimdalı/anasanat dalı bulunan enstitülere tahsis edilmesi şeklindedir (madde4/1). Yönetmeliğe göre yükseköğretim kurumlarında norm kadro planlaması üç şekilde yapılabilmektedir (madde 4/2). Bunlardan ilki, YÖK tarafından Bölgesel Kalkınma Odaklı

\footnotetext{
${ }^{15}$ Devlet Yükseköğretim Kurumlarında Öğretim Elemanı Norm Kadrolarının Belirlenmesine ve Kullanılmasına İlişkin Yönetmelik, RG. 02.11.2018, 30583
} 
Misyon Farklılaşması ve İhtisaslaşma kapsamında belirlenen yükseköğretim kurumları, ihtisas alanlarıyla doğrudan ilgili birimleri için asgari kadro sayısını üç katına kadar; ikincisi, Araştırma Üniversitesi olarak belirlenen yükseköğretim kurumları ise dört katına kadar; üçüncüsü, diğer üniversite ya da birimler norm kadrolarını asgari kadro sayısının iki katına kadar planlayabilir.

YÖK tarafından diş hekimliği programı, eczacılık programı, tıp programı, sağlık, sağlıkla ilgili veya ilişkili programlar ile mühendislik programlarına asgari kadro sayıları belirlenmiştir (https://www.yok.gov.tr). Bu kadrolar incelendiğinde ilgi alanlarda eğitim ve öğretime başlangıç için belirlenen asgari öğretim üyesi sayısı ile eğitim ve öğretimin üçüncü yılı sonuna kadar sağlanması gereken asgari öğretim üyesi ve/veya öğretim elemanı sayısı olmak üzere iki tip asgari kadrodan bahsedilmektedir. Bu alanlar dişında fakülte veya bölüm lisans programları için norm kadrolar, üniversiteler tarafindan anabilim/anasanat dalı çeşitliliği göz önünde bulundurularak bunların her birine bir öğretim üyesi düşecek şekilde planlanır. $\mathrm{Bu}$ doğrultuda belirlenen norm kadro sayıları, anabilim/anasanat dalı ve bölüm kurulunun (...) görüşü üzerine ilgili fakülte ve üniversite yönetim kurulunun gerekçeli kararıyla bölüm veya fakülte düzeyinde iki katına kadar artırılabilir.

Yükseköğretim kurumlarında bahsedilen bu norm kadroların yeterli olmaması durumunda norm dişı kadro talebinde bulunulabileceği dile getirilmektedir. Norm dişı kadro talebi olan ilgili anabilim/anasanat dalı ve bölüm kurulunun görüşü, ilgili birim ve üniversite yönetim kurulunun gerekçeli kararı ile YÖK’e iletilir. YÖK bu talebi, “öğretim üyesi başına düşen öğrenci sayısı, ileri düzey araştırma ve geliştirme faaliyetleri, doktora ve dengi programlarından mezun sayısı, üniversitenin eğitim ve öğretim dışında yürüttüğü hizmetleri dikkate alarak değerlendirir ve karara varır" (Madde 4/3). Rektör üniversitesinde asgari kadrolar ile YÖK tarafından uygun görülen norm dışı kadroların kullanımını koordine eder (Madde 5/2).

Öğretim elemanı asgari kadro sayısını aşan bütün atamalarda asgari kadrolar da dahil olmak üzere kadroların en fazla 2/3'ü aynı unvan için kullanılırken çıkan sayı küsuratlı ise aşağıya doğru yuvarlanacaktır (Madde 5/4). Bu fikraya 2019 yılında eklenen cümleyle yükseköğretim kurumlarının talebi ve YÖK'ün öğretim üyesi temininde güçlük çekildiğine dair verdiği karar üzerine ilgili birimlerdeki doktor öğretim üyesi kadroları ile meslek yüksekokullarında 2/3 şartı aranmayacaktır. Aslında bu durum daha önce 2547 sayılı Kanun'un 7. maddesi f fikrasında YÖK’ün görevleri sıralanırken “üniversitelerin ihtiyaçlarını, eğitim-öğretim programlarını, bilim dallarının niteliklerini, araştırma faaliyetlerini, uygulama alanlarını, bina, araç, gereç ve benzeri imkânlar ve öğrenci sayılarını ve diğer ilgili hususları dikkate alarak; üniversitelerin profesör, doçent ve doktor öğretim üyesi kadrolarını dengeli bir oranda tespit etmek" şeklinde ifade edilmiştir. Norm kadro yönetmeliğinde ise birebir oransal değer verilmiş ve kurum içi akademik camiada terfi olarak adlandırılan atamaların kısıtlandığı gözlemlenmiştir.

Akademik personel yetiştirmek adına istihdam edilen araştırma görevliliği kadrolarında ise yönetmelikte iki kıstasa yer verilmiştir. Bunlardan ilki, Cumhurbaşkanı kararıyla öğretim üyesi dışındaki öğretim elemanı kadroları için belirlenen ilave atama izinlerinin en fazla \%20'sini kapsayacağı şeklindedir. Bu oran YÖK tarafından ülkenin kalkınmasında ve bilim hayatının gelişmesinde öncelikli görülen alanlarda lisansüstü eğitim amacıyla kullandırılmak üzere yükseköğretim kurumlarının araştırma görevlisi kadrolarına tahsis edilir. İkincisi ise bu kapsam dışındaki araştırma görevlisi norm kadroları; öğrenci sayısı, araştırma, proje 
geliştirme gibi faaliyetler dikkate alınarak ilgili birim yönetim kurulunun görüşü üzerine üniversite yönetim kurulu tarafından belirlenir (Madde 4/7).

\section{AKADEMIK PERSONEL IÇiN UYGULANAN NORM KADRO DÜZENLEMESiYLE ORTAYA ÇIKAN SORUNLAR}

Akademisyenler açısından norm kadro düzenlemelerinin çok kısa sürede sisteme dahil edilmesi, çeşitli sorunları da beraberinde getirmiştir. Literatüre yansıyan ve eleştirilere konu olan istihdam ve terfi boyutunda yaşanan ve yaşanması muhtemel olan bu sorunlar çalışma açısından önem arz etmektedir. İlgili başlık altında Yönetmelik çerçevesinde akademik camiada yaşanacak genel sorunlarla birlikte bu iki boyut da ele alınmaktadır.

1990'ların ikinci yarısıyla birlikte kamu personel sistemleri içinde uygulanması daha fazla gündeme gelen norm kadro olgusunu Yılmaz ve Özdem (2004) henüz üniversitelerde norm kadro düzenlemesi yapılmamışken ele almaktadır. Bu çalışmada üniversitelerin kendine özgü niteliklerinin olması ve akademik kadrolarda faklı çalışma koşullarının bulunması nedeniyle norm kadro düzenlemesinin diğer örgütlerdeki kadar kolay olmayacağını vurgulamışlardır. Aslında yazarlar ilgili çalışmada norm kadro uygulamalarının üniversitelerde de yapılabileceğine işaret etmiş, ancak dikkat edilmesi gereken noktaları da birer birer vurgulamışlardır. Bu noktalar; üniversitelerde norm kadro düzenlemelerin yasal bir zorunluluk olarak getirilecekse geniş katılımlı bir zeminde tartışılarak, üniversiteler/fakülteler/birimler arası akademik personelin görev tanımları ayrı ayrı düşünülerek, gerekirse her üniversitenin/fakültenin/birimin kendi ölçütlerini geliştirmesine olanak tanınarak yapılabileceği şeklindedir. Ne yazık ki 2018 yılı Temmuz ayında devlet üniversiteleri için norm kadro standartlarının belirlenmesi gerektiğine ilişkin Cumhurbaşkanlığı Kararnamesi ardından geçen üç ay gibi kısa bir süre zarfında yönetmelik yayımlanmıştır. Yönetmelikte 2019 ve 2020 yıllarında çeşitli düzenlemeler yapılmıştır. Bu düzenlemelerden birisi (Yönetmelikteki ilgili madenin ilk haliyle uygulanması durumunda) son yıllarda açılan üniversitelerin istihdamında ciddi sorunlar ortaya çıkaracağından dolayı gerçekleştirilmiştir. Özellikle öğretim üyesi temininde zorluk yaşayan bu üniversitelerin $2 / 3$ kuralına takılarak yeni öğretim üyesi istihdamını zorlaştıracağından dolayı 5 . madde 4. fikraya bu mağduriyeti giderecek bir fikra eklenmiştir.

Baki ve Acar (2020) plansız, programsız ve yeterince üzerinde durulmadan çıkarılan bu yönetmeliğe yönelik akademide çeşitli eleştirilerin olduğuna dikkat çekmiştir. Özellikle üzerinde durduğu konu ise üniversitelerde farklı yapıları olan fakülteler için tek düzenlemenin getirilmesidir. Bahsettiği tek düzen fakülte veya bölümdeki anabilim/anasanat dalına göre norm kadro düzenlemelerinin yapılmasının uygun görülmesidir. Üzümcü (2020) tarafindan gerçekleştirilen çalışmada yeni açılan bazı alanlarla (fakültelerle) birlikte anabilim dalları azaltılarak değiştirilen bölümlerde anabilim dalıyla belirlenen norm kadrolarda da zamanla azalma yaşanacağına işaret edilmiştir. Bu duruma binaen uzun vadede bu bölümler öğretim üyesi ve öğrenci yönünden fakirleşecektir.

Demir ve Demir (2019) tarafından gerçekleştirilen çalışmada ise akademik personelin zihninde norm kadro uygulamasına yönelik soru işaretleri olduğu tespit edilmiştir. $\mathrm{Bu}$ soru işaretleri çalışmada; norm kadro uygulamasının gerekçelerinin tam olarak anlaşılmaması ya da anlatılmaması, uygulamada üniversitelerde, bölümlerde ve birimlerde yaşanan belirsizlikler, kadro ilanlarının gecikmesi gibi aksamaların yaşanmasıyla ortaya çıkmaktadır. Çalışmaya katılanlar, devlet üniversitelerindeki norm kadro uygulamalarının gerekliliği 
konusunda iki görüş beyan etmiştir. Bunlardan ilki norm kadro ölçütlerinin yeniden düzenlenerek üniversitelerde uygulaması gerektiği yönündeyken diğer görüş uygulamanın üniversitelerde tamamen kaldırılması yönündedir.

Karataş ve Avcı (2019) üniversitelerde 2018 sonrasında uygulanmaya başlayan norm kadro düzenlemeleri için akademisyenlerin algılarını ve ortaya çıkan bu durumla başa çıkma potansiyellerini ölçmeyi hedefleyen bir ölçek geliştirmişlerdir. Çalışmada elde edilen bulgular doğrultusunda bireyin bu değişimle başa çıkma potansiyelinde oldukça etkili olan yapısal faktörün akademik unvan olduğu tespit edilmiştir. Ayrıca üniversitelerdeki norm kadro düzenlemelerinin profesör doktor unvanı dışında kalan öğretim elemanlarını etkilediği gözlemlenmiştir. Özellikle ilerleyen süreçte kurumlarda çalışan öğretim elemanlarının akademik terfilerinde belirsizliklerin ortaya çıkacağı ve bu durumun bireysel kaygılarını artıracağı vurgulanmıştır (Karataş ve Avc1, 2019: 455). Bu tip kaygılar Uğuz-Arsu vd. (2020) tarafından gerçekleştirilen ve araştırma görevlilerini örneklem olarak seçen başka bir çalışmada dile getirilmiştir. Örneklem seçilen grubun kariyer deneyimleri açısından belirttikleri ifadelerde "norm kadro" sözcüğü öne çıkarken; bundan dolayı "alanında kadro alamama" gibi ifadeler kullanmış ve araştırma görevlilerinin geleceğe yönelik kaygıları vurgulanmıştır. Dolayısıyla konuya ilişkin gerçekleştirilen çalışmaların genelinde üniversitelerdeki norm kadro düzenlemelerinin akademik personel açısından kariyer gelişimleri yönünde negatif etkisi olduğu gözlemlenmiştir.

\section{SONUÇ VE ÖNERiLER}

Üniversitelerin temel misyonu bilimsel bilginin üretilmesi, yayılması ve nitelikli iş gücünün yetiştirilmesidir. $\mathrm{Bu}$ çerçevede özellikle nitelikli öğretim elemanlarını/öğretim üyelerini istihdam etmesi gerekmektedir. Kamusal kaynakların israf edilmemesi adına önceden belirlenen standartlarda nicel ve nitel yeterlilikleri (norm kadro standartları) tasnif edilen akademik personelin istihdamı önem arz eden bir konudur.

Türkiye'deki devlet üniversitelerinde norm kadro düzenlemeleri 2018 yılında 2 sayılı Cumhurbaşkanlığı Kararnamesi ile gündeme gelmiş ve yine aynı yıl Yükseköğretim Kurumu tarafından çıkarılan yönetmelikle uygulamaya başlanmıştır. Gündeme gelişi ve yasal zemine adaptasyonun çok kısa süre zarfında olması özellikle başlangıçta yönetmeliğin anlaşılmasında çeşitli sorunları da beraberinde getirmiştir. Bu sorunların bir kısmı 2019-2020 yıllarında yönetmeliğe yapılan çeşitli eklemeler ve mülga ifadelerle giderilmeye çalışılmıştır. Ancak yönetmelikte anlaşılma sorunu yanı sıra akademik alanla ilgili çeşitli sorunlar da varlık göstermektedir. Literatüre bunların bir kısmı yansırken diğer bir kısmı uygulamanın daha yeni olmasından dolayı sadece söylemde kalmaktadır. Yönetmeliğe ilişkin dikkat çeken bu sorunları belirli konular çerçevesinde toparlamak gerekmektedir. Bunlardan ilki kavramsal çerçevenin belirlenmesiyle ilişkilidir. Yönetmelikte asgari kadro sayısı, norm kadro ve norm dışı kadro kavramları bulunmaktadır. Bu kapsamda üniversitelerin içinde bulundukları durumların dikkate alınmaması ve seçilen birkaç alan dışındaki bölümlerde asgari ya da norm kadro sayısının anabilim/sanat dallarına göre planlanması sorunsalı karşımıza çıkmaktadır. Norm dışı kadro uygulamalarında ise kurumun yönetmelikte belirlenen gerekçeli istemi üzerine kadroların YÖK tarafından verileceği dile getirilmiş, kadronun kullanımı ise rektöre bırakılmıştır. Dolayısıyla norm dışı kadro talebinde kurumlar ve birimler arası farklılıkların akademik açıdan fırsat eşitliğini zedeleyecek şekilde olduğu yönünde eleştirilere sebep olmaktadır. Ayrıca yönetmelikte öğretim üyesi ve öğretim elemanı kavramlarının aynı madde içinde dile getirilmesi kafa karışıklığına neden olabilmektedir. 
Yönetmeliğin uygulanmasına ilişkin ikinci temel sorun üniversitelerde hâkim olan personel sistemiyle ilişkilidir. Üniversite istihdam çeşitliliği farklılık gösteren personel kitlesine sahip kamu kurumlarından biridir. Bu kurumlarda farklı yasal düzenlemelere tabi idari ve akademik personel ayrımının var olduğu; mesleğe özgü yasal çerçevede toplansa da akademik kadro unvanları arasında dahi farklı kamu personel sistemlerinin izlerine rastlandığı göz ardı edilmemelidir. Yönetmelik kapsamında idari ve akademik personel ayrımı gözetilse de ne yazık ki akademik unvanlar arasındaki istihdam farklılığ 1 gözetilmemiştir. Üniversitelerde kariyer sisteminin işletildiği, ömür boyu iş garantisi verilen idari personeli örneklem olarak seçen İyem vd. (2016) tarafından gerçekleştirilen bir çalışmada; norm kadro çalışmalarının sağlıklı bir şekilde yapılması kurumsal verimliliği ve motivasyon düzeyini artıracağ1 belirtilirken uygulanabilirliği konusunda olumsuz algıların yaygınlığına dikkat çekilmiştir. Ayrıca araştırma görevlilerini örneklem olarak seçen Uğuz-Arsu vd. (2020) tarafindan gerçekleştirilen çalışma bu temel sorunun derinleşeceğini, kariyer ve kadro sisteminin birlikte uygulandığı akademik personelde uygulamanın özellikle iş güvencesi açısından duyulan endişeyi daha fazla belirginleştireceğini göstermektedir.

Doğan, Demir ve Pınar (2014) ile Memişoğlu ve İsmetoğlu (2013) tarafından belirtildiği gibi Milli Eğitim Bakanlığ bünyesinde uygulanan norm kadro düzenlemeleri öğretmenlerin norm fazlası sorunu yaşanmasına neden olmuştur. Akademide ilgili yönetmelik kapsamında hali hazırda üniversitede istihdam edilen ve norm fazlası olan kadrolar açısından öğretim elemanlarının bulunduğu kadrolarda görev yapması koşuluyla bu sorun kısmen giderilmeye çalışılmıştır. Ancak bu uygulama personel düzenlemeleri açısından akademisyenlerin öğretmenlerden farklı bir yasal düzenlemeye ve akademik hiyerarşiye tabi olmalarından kaynaklı geçici bir çözüm olarak gözlemlenmekte ve üniversitelerde norm kadro uygulamalarının özümsenmesini geciktirecek diğer bir sorun olarak karşımıza çıkmaktadır.

Yönetmeliğin hazırlanma sürecinde norm kadro sayısının belirlenmesine ilişkin kriterlerin üzerinde ne kadar düşünüldüğü sorunsalı değinilmesi gereken bir diğer konudur. İlgili birimde, anabilim/anasanat dalında norm kadrolar belirlenirken dönemlik olarak öğretim üyesine düşen (lisans varsa master ve/veya doktora) ders sayısı, uygulamalı bilimler için sahada geçirdikleri süre, danışmanlık hizmeti, akademik açıdan beklenen performans, kurum piyasa ilişkisi, kurumun beklentisi doğrultusunda alacağı idari görevler gibi iş yükleri üzerinde yeterince çalışılmadan tespit edildiği düşüncesi hâkimdir. Bu yüzden akademik camiada norm kadronun nitelik ve nicelik yönünden yeterli insan gücünü sağlayamayacağ1 düşünülmektedir. Ek olarak akademisyenler, düşünsel temeller üzerine faaliyet göstermesi beklenen ve bilgi üreticileri olmaları arzulanan personel grubudur. Onlar için ders ve idari görevler dışında mesai kavramı bulunmamaktadır. $\mathrm{Bu}$ alanda iş ölçüm yönteminin yapılmasının ne derece doğru sonuçlar vereceği tespit edilememektedir. Norm kadro saptamasında kullanılan yöntemlerin akademisyenlik mesleğinin doğasına ilişkin ölçülmesi güç bu alanları nasıl ve ne şekilde ölçeceği üzerinde uzun uzun düşünülmesi gerekmektedir.

Öğretim üyelerinin kurumlarda hiyerarşik olarak dengelenmesini sağlayacağı öngörülen 2/3 oranı akademik terfilerde norm kadro yönetmeliği ile karşımıza çıkan bir diğer sorundur. Norm kadro uygulamalarının temelini aldığı insan kaynakları yönetiminin kamu personel sistemine entegre edilmesiyle kurumsal beklentilerin yanı sıra iş görenlerin kariyer beklentilerinin de birlikte yürütülmesi gerekliliği bu oranla göz ardı edilmektedir. Standart olarak tek başına derece yükseltilmesi kademe ilerlemesi kuralına bağlı olmayan, akademik personel açısından idari üst görevlerden daha fazla öneme sahip olan akademik kariyer için 
getirilen bu kuralın sorgulanması gerekmektedir. Öncelikle doçentlik unvanını 2547 sayılı Kanun'da belirlenen kriterlerin geçilmesiyle alan akademik personelin kurumdaki terfisinin engellenmesi motivasyon, iş tatmini, örgütsel bağlılık, örgütsel barış gibi insan kaynakları yönetiminin önemli değerlerini zedeleyecektir. Bu değerlere negatif etkide bulunacak bir diğer atama da kurumda doçentlik kadrosunda istihdam edilirken profesör kadrosu almayı hak eden öğretim üyeleridir. Akademik açıdan meşakkatli bir yolun sonuna gelen ve diğer kaygılarını bırakıp bilime katkı düzeyleri yüksek olabilecek akademik unvana sahip bu öğretim üyelerinin oran kuralının gerekçe gösterilerek atanmadıkları görülmektedir. Böylece farklı arayışlar içine giren norm kadro düzenlemeleriyle kurumda hak ettiği kadroda istihdam edilemeyen doçent ya da profesörler özellikle gelişim düzeyi yüksek illerdeki diğer üniversitelerde bu arayışlarını sürdürecektir. Ayrıca nitelikli işgücü olarak tanımlayacağımız bu personel kamusal alan dışında özel sektöre kayacaktır. Oransal bu uygulamanın yeni ve/veya gelişim düzeyi düşük illerde kurulan üniversitelere nitelikli işgücü temini açısından yapıldığ 1 ifade edilse de (öğretim elemanlarının bu düzenlemeyle bu üniversitelere rakip gelişmiş illerdeki ikincil üniversitelere veya özel sektöre kaymasından dolayı) bu üniversitelerde istenen bilimsel kaliteye ulaşılması yine gecikecektir. Diğer devlet üniversitelerinde ise akademik açıdan nitelikli personel kaybı yaşanacak bilimsel bilginin üretilmesi, yayılması ve nitelikli iş gücünün yetiştirilmesi konusunda dengeler değişecektir.

Yönetmelik kapsamında araştırma görevliliği istihdamı öğretim üyeliği istihdam ve terfiine oranla nispeten daha serbest bırakılmıştır. Ancak lisansüstü eğitimin oldukça zorlu bir süreç olması ve doktor unvanı alan kişilere kamusal alandaki istihdam kapılarının kısılmasi/kapatılması, öğretim üyeliği yetiştirme amacıyla var olan bu mekanizmayı zedeleyeceği düşünülmektedir.

Baki ve Acar (2020) norm kadro uygulamalarının özellikle eğitim sektöründeki faydalarını; yöneticiler açısından düzensiz kadrolaşmayı önlemesi, nesnel veriler sunularak güvenilirliğin artırılması, kaynakların dengeli kullanılması şeklinde sıralamışlardır. Yerel yönetimler için gerçekleştirilen norm kadro uygulamalarında ise sorunlar yaşansa da özellikle yereldeki istihdam baskılarına karşı yerel siyasetçilere direnme şansı vermesi ve kayırmacılık sorununa çözüm getirmesi açısından artı değerler getirmektedir (Yüceyılmaz ve Özgür, 2019: 83). Ancak akademik alanda durum farkl11ıklar içermektedir. Özellikle profesör ve doçent atamalarıyla birçok idari göreve de getirilme imkânı verilen kadrolar ile idari açıdan daha az paydaş olabilecek doktor öğretim üyeliği kadrolarına yapılan norm dışı atamalarda üniversiteler arasındaki veya üniversite içindeki farklı uygulamalar dikkat çekmektedir. Ayrıca ilerleyen süreçlerde özellikle kadın ve erkek öğretim üyeleri arasında da bu uygulamaya ilişkin farklılıklar ortaya çıkacaktır. Oysaki norm kadro uygulamalarının yerinde ve sağlam bir şekilde yapılıyor olması bir eğitim kurumu olan üniversitelerde de çeşitli faydaları beraberinde getirecektir.

Çalışmada yapılan incelemeler doğrultusunda; üniversitelerdeki norm kadro uygulamalarına tam anlamıyla bir karşı duruşun olmadığı tespit edilmiştir. Ancak yönetmeliğe ilişkin yerinde çeşitli eleştirilerinde yapıldığı gözlemlenmektedir. Bu doğrultuda özellikle akademik kadro çeşitliliğinde uygulanan karma personel sistemi (kariyer-kadro sistemleri) dikkate alınarak yönetmeliğin tekrardan gözden geçirilip düzenlenmesi önerilmektedir. Üniversitelerde daha etkin bir norm kadro uygulamasına geçilmesi adına;

- Birkaç üniversite (kurulum tarihlerine göre gruplandırılabilir) çalışmaya dahil edilmeli, 
- $\mathrm{Bu}$ üniversitelerde birbiriyle paralel eğitim veren fakülte/bölümleri karşılaştırma olanağı tanınmalı,

- Konu hakkında uzman olan akademisyenlerden oluşan çalışma grupları oluşturulmal1,

- Asgari kadro tekrardan kurumsal geri dönüşlerle birlikte birimler arası farklılıklar da dikkate alınarak yeniden belirlenmeli,

- Öğretim üyesinden beklenen görev ve iş yükleri daha iyi tespit edilerek bu kapsamda norm kadro sayıları yeniden düşünülmeli,

- İş analizi yardımıyla sürece yayılarak oluşturulacak iş tanımı ve gerekleri belirlenmeli,

- Akademik unvanların oransal değerlere takılarak verilmemesi, ilgili yasal çerçeve göz önüne alınarak yeniden irdelenmeli,

- Örgütsel şemalar tekrar gözden geçirilmelidir. Bu doğrultuda standartları, nitelikleri ve niceliği belirlenen norm kadro standartları oluşturulmalıdır.

\section{KAYNAKÇA}

ALBAYRAK, S. (2020). "Türkiye'de Kamu Personel Yönetiminin Yeni Kurumsal Yapısı ve Kamu İstihdamının Yeni Görünümü”. Ankara Üniversitesi SBF Dergisi, 75(4): 1517 1549 .

ASLAN, O. E. (2006). Kamu Personel Rejiminin Anayasal İlkeleri. TODAİE Yayını, Ankara.

ASLAN, O. E. (2012). Devlet Bürokrasi ve Kamu Personel Rejimi. 2. Baskı, İmge Kitabevi, Ankara.

AYKAÇ, B. (1999). İnsan Kaynakları Yönetimi ve İnsan Kaynaklarının Stratejik Planlaması. Nobel Yayınları, Ankara.

AYMAN-GÜLER, B. (2013). Kamu Personeli: Sistem ve Yönetim. 2. Baskı, İmge Kitabevi, Ankara.

BAKİ, F. ve ACAR, O. K. (2020). "Milli Eğitim Bakanlığında Norm Kadro Uygulaması: Isparta İlinde Okul Yöneticileri Üzerinden Bir Değerlendirme”. Selçuk Üniversitesi Sosyal Bilimler Enstitüsü Dergisi, 44: 141-150.

BİLGIN, K. U. ve AYTÜRK, N. (2003). “Türkiye’de Kamu Kuruluşlarında Norm Kadro". Türk İdare Dergisi, 438: 157-179.

BOZKURT, Ö., ERGUN, T. ve SEZEN, S. (1998). Kamu Yönetimi Sözlüğü. TODAİE Yayınları, Ankara.

DEMİR, R. ve DEMİR, M. (2019). "Kamu Üniversitelerinde Çalışan Akademisyenlerin Norm Kadro Uygulamasına Yönelik Görüşlerinin Belirlenmesine İlişkin Bir Araştırma”. İşletme Araştırmaları Dergisi, 11(4): 2492-2511.

DEMİRKAN, M. (2003). "Kamuda İnsan Kaynakları Planlaması ve Norm Kadro Çalışmalarına İlişskin Bir Değerlendirme”. Siyasal Vakfı Bülteni, 9(14): 15-18. 
DOĞAN, S., DEMIR, S. B. ve PINAR, M. A. (2014). "4+4+4 Kesintili Zorunlu Eğitim Sisteminin Sınıf Öğretmenlerinin Görüşleri Doğrultusunda Değerlendirilmesi”. Elementary Education Online, 13(2): 503-517.

DPT (1989). Altıncı Beş Yıllık Kalkınma Planı, Ankara: Devlet Planlama Teşkilatı Yayını.

DPT (1995). Yedinci Beş Yıllık Kalkınma Planı, https://www.sbb.gov.tr/wpcontent/uploads/2018/11/Yedinci-Be\%C5\%9F-Y\%C4\%B111\%C4\%B1k-

Kalk\%C4\%B1nma-Plan\%C4\%B1-1996-2000\%E2\%80\%8B.pdf/18:12:2020.

DPT (2000). Uzun Vadeli Strateji ve Sekizinci Beş Yıllık Kalkınma Planı, https://www.sbb.gov.tr/wp-content/uploads/2018/11/Sekizinci-Be\%C5\%9F-

Y\%C4\%B111\%C4\%B1k-Kalk\%C4\%B1nma-Plan\%C4\%B1-20012005.pdf/18.12.2020.

DPT (2006). Dokuzuncu Kalkınma Plan1, https://www.sbb.gov.tr/wpcontent/uploads/2018/11/Dokuzuncu-Kalk\%C4\%B1nma-Plan\%C4\%B1-20072013\%E2\%80\%8B.pdf/18.02.2020.

EREN, V. (2006). "Personel Yönetiminde Bürokratik Modelden İşletmeci Anlayışa Geçiş". Selçuk Üniversitesi İİBF Sosyal ve Ekonomik Araştırmalar Dergisi, 6 (11): 131-153.

GÜNEŞER-DEMIRCİ, A. (2010). “Bir Politika Transferi Örneği Olarak Türkiye’de Kadro Sisteminin İnşası”. Toplum ve Demokrasi, 4 (8-9-10): 143-168.

IYYEM, C., ÖZDEMIR, Y., ARSLAN-DİŞLİ, G. ve YILMAZ, C. (2016). "Kamu Çalışanlarının Norm Kadro Algıları: Bir Devlet Üniversitesi Örneği”. Balkan Sosyal Bilimler Dergisi, Özel Sayı: 182-203.

KALKANDELEN, A. H. (1972). Personel Yönetimi ve Yönetimde Sistemler-İlkeler. Şenyuva Matbaası, Ankara.

KARATAŞ, A. ve ANCİ, S. B. (2019). "Yükseköğretimde Norm Kadro Değişikliği Sonucu Aktörlerin Başa Çıkabilme Potansiyelinin Değerlendirilmesi: Bir Ölçek Geliştirme Çalışması”. Erzincan Üniversitesi Sosyal Bilimler Enstitüsü Dergisi, 12(2): 439-460.

KAYAR, N. (2020). Kamu Personel Yönetimi. Güncellenmiş 10. Baskı, Ekin Yayınevi, Bursa.

KESTANE, D. (2003). "Performansa Dayalı Ücret Sistemi ve Kamu Kesiminde Uygulanabilirliği”, Maliye Dergisi, 142: 126-144.

MEMIŞOĞLU, S. P. ve İSMETOĞLU, M. (2013). "Zorunlu Eğitimde 4+4+4 Uygulamasına İlişkin Okul Yöneticilerinin Görüşleri”. Eğitim ve Öğretim Araştırmaları Dergisi, 2(2): 14-25.

ONAR, S. S. (1952). İdare Hukukunun Umumi Esasları, Marifet Matbaası, İstanbul.

ÖKTEM, M. K. (1990). "Kamu Yönetiminde İnsangücü Planlaması: Kavramsal Bir Çerçeve”. Amme İdaresi Dergisi, 23(1): 13-38.

ÖMÜRGÖNÜLŞEN, U. ve ÖKTEM, M. K. (2004). "Kamu Görevlileri ile Kamu Görevlileri Sendikalarının Kamu Sektöründeki Norm Kadro Çalışmalarına Karşı Tutumları". Hacettepe Üniversitesi İktisadi ve İdari Bilimler Fakültesi Dergisi, 22(1): 249-263. 
ÖZER, M. A., SÖKMEN, A., AKÇAKAY, M. ve ÖZAYDIN, M. M. (2019). İnsan Kaynakları Yönetimi. Güncellenmiş 2. Baskı, Gazi Kitabevi, Ankara.

ÖZKAL-SAYAN, İ. (2009). “Türkiye'de Kamu Personel Sistemi: İdari, Askeri, Akademik, Adli Personel Ayrımı”. Ankara Üniversitesi SBF Dergisi, 64(1): 201-245.

SÜMER, H. C. ve EROL, T. (2003). "Kamu Kuruluşlarında Yeniden Yapılanma: Bir Norm Kadro Çalışması”. Türk Psikoloji Dergisi, 18(52): 97-114.

ŞAYLAN, G. (2000). Kamu Personel Yönetiminden İnsan Kaynakları Yönetimine Geçiş: Kritik ve Reform Önerileri. TESEV, İstanbul.

T.C. Kalkınma Bakanlığı (2013). Onuncu Kalkınma Planı, https://www.sbb.gov.tr/wpcontent/uploads/2018/11/Onuncu-Kalk\%C4\%B1nma-Plan\%C4\%B1-20142018.pdf/18.12.2020.

T.C. Cumhurbaşkanlığı Strateji ve Bütçe Başkanlığı (2018) On Birinci Kalkınma Planı, https://www.sbb.gov.tr/wp-content/uploads/2019/07/On-Birinci-Kalkinma-

Plani.pdf/18.12.2020.

TİMUR, H. (2004). "Norm Kadro Saptama Teknikleri ve Norm Kadro Kilavuzunu Hazırlama Yöntemi”. Hacettepe Üniversitesi İktisadi ve İdari Bilimler Fakültesi Dergisi, 22(2): 201-221.

TORTOP, N., AYKAÇ, B., YAYMAN, H. ve ÖZER, M. A. (2013). İnsan Kaynakları Yönetimi, Nobel Yayınları, Ankara.

UĞUZ-ARSU, Ş., SUNMAN, G., ORUÇ, Ş. ve TEKİNDAL, M. (2020). "Türkiye'de Gelişmekte Olan Üniversitede Araştırma Görevlisi Olma Deneyimi: Nitel Bir Araştırma", Ufkun Ötesi Bilim Dergisi, 20(1): 109-152.

ÜZÜMCÜ, M. (2020). “İlahiyat Fakülteleri Felsefe ve Din Bilimleri Bölümlerinde Akademik Yapılanma ve Lisansüstü Eğitim Üzerine Bir Değerlendirme”. Mevzu Sosyal Bilimler Dergisi, 3: 167-192.

YILMAZ, K. ve ÖZDEM, G. (2004). "Norm Kadro Çalışmalarının Üniversitelerde Uygulanabilirliği: Nitel Bir Araştırma”. Ankara Üniversitesi Eğitim Bilimleri Fakültesi Dergisi, 37(2): 115-136.

YÜCEYILMAZ, H. ve ÖZGÜR, H. (2019). "Eski Hikâye, Yeni Uygulama; Belediyelerde Norm Kadro: Aydın İli Belediyeleri Araştırması”. Çağdaş Yerel Yönetimler Dergisi, 28(1-2): 81-114

2 sayılı Genel Kadro ve Usulü Hakkında Cumhurbaşkanlığı Kararnamesi, RG. 10.07.2018, 30474, https://www.resmigazete.gov.tr/eskiler/2018/07/20180710.htm, 26.12.2020.

2001/39 Sayılı Başbakanlık Genelgesi, RG. 11.07.2001, 24459, https://www.resmigazete.gov.tr/eskiler/2001/07/20010711.htm\#11, 24.12.2020.

2547 sayılı Yükseköğretim Kanunu, RG. 6.11.1981, 17506, https://www.mevzuat.gov.tr/MevzuatMetin/1.5.2547.pdf, 20.12.2020.

2914 sayılı Yükseköğretim Personel Kanun, RG. 13.10.1983, 18190, https://www.mevzuat.gov.tr/MevzuatMetin/1.5.2914.pdf, 20.12.2020. 
say1l Devlet Memurları Kanunu, RG: 13.07.1965, 12056, https://www.mevzuat.gov.tr/mevzuat?MevzuatNo=657\&MevzuatTur=1\&MevzuatTert ip $=5 / 21.12 .2020$.

703 sayılı Anayasada Yapılan Değişikliklere Uyum Sağlanması Amacıyla Bazı Kanun ve Kanun Hükmünde Kararnamelerde Değişiklik Yapılması Hakkında Kanun Hükmünde Kararname, RG.

09.07.2018, 30473.https://www.resmigazete.gov.tr/eskiler/2018/07/20180709M3.htm, 26.12.2020.

Bakanlar Kurulu Karar1 2000/1658, RG. 20.12.2000, 24266, https://www.resmigazete.gov.tr/eskiler/2000/12/20001220.htm\#1/11.12.2020.

Belediye ve Bağlı Kuruluşları ile Mahalli İdare Birlikleri Norm Kadro İlke ve Standartlarına Dair Yönetmelik, RG. 22.02.2007, 26442, https://www.mevzuat.gov.tr/mevzuat?MevzuatNo=11125\&MevzuatTur=7\&MevzuatT ertip $=5,27.12 .2020$.

Devlet Yükseköğretim Kurumlarında Öğretim Elemanı Norm Kadrolarının Belirlenmesine ve Kullanılmasına İlişkin Yönetmelik, RG. 02.11.2018, 30583, https://www.mevzuat.gov.tr/File/GeneratePdf?mevzuatNo=27923\&mevzuatTur=Kuru mVeKurulusYonetmeligi\&mevzuatTertip=5, 05.12.2020.

İl Özel İdareleri Norm Kadro İlke ve Standartlarına Dair Yönetmelik, RG. 10.06.2007, 26548 ,

https://www.mevzuat.gov.tr/mevzuat?MevzuatNo=11369\&MevzuatTur=7\&MevzuatT ertip=5, 27.12.2020.

Millî Eğitim Bakanlığı'na Bağlı Eğitim Kurumları Yönetici ve Öğretmenlerinin Norm Kadrolarına İlişkin Yönetmelik, RG. 18.06.2014, 29034, https://www.mevzuat.gov.tr/MevzuatMetin/21.5.20146459.pdf, 11.12.2020.

Sosyal Sigortalar Kurumu Başkanlığı Merkez ve Taşra Teşkilatının Norm Kadrolarına İlişkin Yönetmelik, RG. 17.12.1999, 23909, https://www.resmigazete.gov.tr/arsiv/23909.pdf, 26.12.2020.

https://sozluk.gov.tr/07.12.2020.

https://www.yok.gov.tr/kurumsal/idari-birimler/egitim-ogretim-dairesi/asgari-kosullar, 16.01.2021. 